\title{
PERAN BADAN KEPENDUDUKAN DAN KELUARGA BERENCANA NASIONAL (BKKBN) PROVINSI BENGKULU DALAM PELATIHAN PETUGAS LAPANGAN KELUARGA BERENCANA (PLKB)
}

\author{
Oleh \\ ELI ERMAWATI, ANTONIO IMANDA, ASNAWATI \\ Program Studi Administrasi Publik Fakultas Ilmu-Ilmu Sosial \\ Universitas Dehasen Bengkulu
}

\begin{abstract}
This research was conducted at BKKBN Branch office bengkulu Province, training and developing (Latbang). This research purpose is to find out the role of BKKBN Bengkulu province in Training of Family Planning field officer. This research uses descriptive qualitative method. Data is collected thru observation, interview and documentation. Faried Ali (2011) theory is used in this research. The result of this research shows that the roles of $B K K B N$ in PLKB training are: (1) Stabilizator, PLKB can increase the knowledge and ability in PLKB Training, it can be seen from pre-test and post-test. But not in all PLKB trainers can increase their skills because some of them weren't listening or taking a note, some of them playing with their smartphone and talking; (2) Dinamisator, the process of PLKB training started by holding a preparation meeting. In that meeting, materials are discussed, training time, administration preparation like correspondence and financial, also facility in training; (3) Inovator, BKKBN found new things in PLKB Training because there was an evaluation after training, observation, suggestions, all trainees can give suggestion about the training. BKKBN also give material according to PLKB need and has provide the material professionally because they split time into discussion, working group, field practive, refreshing (outbound) and follow-up.
\end{abstract}

Keywords: role, BKKBN, PLKB, training

\section{PENDAHULUAN}

Pembangunan nasional merupakan perwujudan dari tujuan bangsa Indonesia yang pada intinya bertujuan untuk mewujudkan masyarakat adil dan makmur yang merata baik materil maupun spiritual berdasarkan Pancasila dan Undang-undang Dasar 1945. Pembangunan nasional yang dilaksanakan pada hakekatnya mencakup semua aspek kehidupan manusia yang dilakukan secra terarah, terpadu dan berkesinambungan serta menyeluruh pelosok tanah air.

Kebijakan Program KB Nasional sebelum tahun 2001 ditentukan oleh BKKBN pusat, akan tetapi setelah tahun
2001 kebijakan KB diatur oleh daerah terutama di tingkat Kabupaten/Kota (yang diserahkan adalah kewenangan BKKBN untuk Kabupaten/Kota, untuk kewenangan tingkat Provinsi sampai saat ini belum diserahkan ke daerah dan masih ada di tangan BKKBN pusat).

Kebijakan KB yang diatur oleh pemerintah daerah tersebut antara lain meliputi kebijakan pendanaan program, kelembagaan, ketenagaan sampai dengan kebijakan-kebijakan lain termasuk penentuan permintaan masyarakat mengenai peserta $\mathrm{KB}$ baik $\mathrm{KB}$ aktif maupun baru, di tingkat Kabupaten/Kota 
dari aspek kebijakan pendanaan program kurang memberi alokasi dana, karena keterbatasan dana dan aspek kelembagaan kurang memberi keluasan kewenangan penggarapan program.

Sehubungan dengan perkembangan zaman, Bangsa Indonesia adalah salah satu Negara yang berkembang disegala bidang termasuk di bidang Badan Kependudukan dan Keluarga Berencana Nasional (BKKBN). Dengan adanya kemajuan dalam Program di Badan Kependudukan dan Keluarga Berencana Nasional (BKKBN), Bahwa posisi Petugas Lapangan Keluarga Berencana (PLKB) dalam pengelolaan Program KB Nasional sangat dibutuhkan dengan adanya permasalahan yang ada ditengah masyarakat. PLKB juga menentukan terutama dalam menghadapi perubahan Visi dan Misi Program BKKBN. PLKB perlu dibekali pengetahuan tentang program KB Nasional dengan jelas dalam melakukan pembianan kepada individu, keluarga dan masyarakat di tingkat desa/kelurahan.

\section{Petugas Lapangan Keluarga} Berencana (PLKB) adalah Pegawai Negeri Sipil (PNS) Pusat berkedudukan di Desa/Kelurahan yang bertugas melaksanakan, mengelola, menggerakan, memberdayakan serta menggalang dan mengembangkan kemitraan dengan berbagai pihak dalam pelaksanaan program KKBPK bersama institusi masyarakat pedesaan/perkotaan di tingkat Desa/Kelurahan.

Kita ketahui bersama bahwa posisi PLKB dalam pengelolaaan Program KB Nasional sangat menentukan keberhasilan Program KB atau sekarang dikenal dengan Program Kependudukan Keluarga Berencana dan Pembangunan Keluarga (KKBPK) antara lain ditandai dengan adanya penurunaan laju pertumbuhan pendudukan, penurunan tingkat fertilitas, peningkatan kesadaran masyarakat tentang makna keluarga kecil dan peningkatan kepedulian serta peran masyarakat dalam pengelolaan program KB.
Maka penumbuhan, pembinaan dan pengembangan PLKB perlu terus dikembangkan untuk ikut membina agar program-program tersebut dapat terlaksana dengan baik.

Keberhasilan tersebut tidak terlepas dari keberadaan Petugas Lapangan Keluarga Berencana (PLKB) di lini lapangan sebagai motor penggerak pembangunan yang merupakan perpanjang tangan Satuan Kerja Pemerintah Daerah (SKPD) di tingkat Kelurahan/desa yang ada, agar mereka berhasil mempertahankan eksistensi program Kependudukan Keluarga Berencana dan Pembangunan Keluarga (KKBPK) di lini lapangan di bidang Kependudukan dan Keluarga Berencana.

Tugas utama dari Petugas Lapangan Keluarga Berencana (PLKB) adalah mempertahankan pencapaian angka kesetaraan KB yang tinggi dan mengendalikan angka kelahiran penduduk di wilayah binaannya. Peran Petugas Lapangan Keluarga Berencana (PLKB) memotivasi, membina dan meningkatkan akseptor KB, menjaga hubungan komunikasi dengan keluarga binaan serta menentukan angka kesetaraan yang tinggi berdampak pada penurunan angka kelahiran.

Dampak dari pelaksanaan Petugas Lapangan Keluarga Berencana (PLKB) dalam pembangunan Daerah melalui program KB Nasional dimasa mendatang adalah meningkatkan kualitas program KB untuk memenuhi hak-hak reproduksi, kesehatan reproduksi, pemberdayaan keluarga, pengentasan keluarga miskin, peningkatan kesejahteraan anak, pemberdayaan perempuan dan pengendalian penduduk agar terwujud

keluarga kecil yang bahagia dan sejahtera yang pada akhirnya menuju keluarga berkualitas.

Pemanfaatan pelatihan disuatu instansi pemerintah bertujuan untuk meningkatkan pengetahuan para petugas PLKB. PLKB diharapkan dapat memberikan kontribusi yang maksimal 
dalam melaksanakan Program KB kedepan yang ditentukan akan berpengaruh terhadap pembangunan di Daerah. Perubahan kearah kemajuan ini membuat segala menuju ketingkat keberhasilan yang ditandai adanya penurunan laju Pertumbuhan Pendudukan, Penurunan tingkat kelahiran, peningkatan kesadaran masyarakat tentang makna keluarga kecil, hal ini mencerminkan betapa besarnya peran Petugas Lapangan Keluarga Berencana (PLKB).

Semakin tinggi pengetahuan maka kinerja pegawai akan semakin tinggi. Upaya untuk mencapai kesuksesan di dalam bekerja dituntut pelatihan sesuai dengan tugas yang dipegangnya. Jadi, melalui pelatihan PLKB diharapkan akan bertambah pengetahuan dan keterampilan, makin mudah berpikir secara luas, makin tinggi daya inisiatifnya dan makin mudah pula menemukan cara yang efisien guna menyelesaikan pekerjaannya dengan baik.

Peran sebagai penyuluh PLKB mengkomunikasikan, mengajarkan dan menyampaikan gagasan tentang programprogram KB yang akan dilaksanakan. Oleh karena itu PLKB diharuskan menguasai materi Program KB yang akan disampaikan dan memiliki sifat terbuka dan memiliki keinginan untuk mengajak masyarakat berubah memandang Program KB secara positif. Di samping itu peran PLKB mau mendengar pendapat dan keluhan masyarakat dalam aplikasi pelaksanaan program KB. Sebagai penggerak, PLKB dapat mengajak, mengkoordinasikan, dan meningkatkan partisipasi masyarakat sadar bahwa program-program KB memberikan keuntungan bagi kehidupan masyarakat.

Berdasarkan Undang-Undang

Nomor 52 Tahun 2009 tentang Perkembangan Kependudukan dan Pembangunan Keluarga diarahkan untuk mengendalikan kelahiran dan menurunkan angka kematian. Program Kependudukan dan Keluarga Berencana Nasional, khususnya di Provinsi Bengkulu telah menunjukkan keberhasilan yang dibuktikan dengan adanya penurunan laju pertumbuhan penduduk, fertilitas dan meningkatkannya kesadaran masyarakat akan arti Keluarga Berencana. Untuk saaat ini Angka laju pertumbuhan penduduk Provinsi Bengkulu berada pada angka 2,3 TFR artinya laju pertumbuhan penduduk yang cukup rendah.

Keberhasilan tersebut tidak terlepas dari keberadaan tenaga PLKB di lini lapangan. Oleh karena itu perlu diberikan Pelatihan Kompetensi Tehnis Program KKBPK bagi PLKB Kabupaten/Kota se Provinsi Bengkulu dalam rangka meningkatkan keterampilan dan wawasan tentang program KKBPK untuk mencapai tujuan yang lebih baik untuk menuju pelayanan prima sebagaimana yang diharapkan masyarakat.

BKKBN Provinsi Bengkulu menyelenggarakan pelatihan bagi peserta PLKB sudah menjadi program rutin yang diadakan setiap 1 tahun sekali. Program pelatihan bagi peserta PLKB Kabupaten/Kota se Provinsi Bengkulu Pada tahun 2018 ini pelatihan PLKB dilaksanakan angkatan I dan II pada tanggal 26 Februari s.d 02 Maret 2018, dan angkatan III dan IV pada tanggal 05 s.d 09 Maret 2018. Peserta pelatihan bagi PLKB angkatan I dan angkatan II Kabupaten/Kota se Provinsi Bengkulu berjumlah 68 orang, angkatan III dan angkatan IV Kabupaten/Kota se Provinsi Bengkulu berjumlah 68 orang. Jadi jumlah keseluruhan angkatan I sampai angkatan IV berjumlah 136 orang.

Salah satu kendala dalam pelatihan yang selama ini diselenggarakan oleh BKKBN adalah, kurangnya evaluasi dari BKKBN ke lapangan untuk melihat kinerja dari PLKB setelah mengikuti pelatihan. BKKBN hanya melihat peningkatan PLKB dari hasil pre test dan pro test saja. Jadi setiap sudah pelatihan BKKBN tidak melakukan monitoring ke lapangan, sebaiknya BKKBN turun ke lapangan 3 (tiga) bulan setelah pelatihan. BKKBN turun ke lapangan pada saat ada 
kegiatan saja dan itu pun pada PLKB yang aktif tidak semua PLKB.

Di lapangan, harapan besar yang dibebankan kepada Petugas Lapangan Keluarga Berencana (PLKB) ternyata masih diliputi berbagai kendala yang menyangkut kinerja Petugas Lapangan Keluarga Berencana di lapangan, antara lain meliputi: (1) jumlah Petugas Lapangan Keluarga Berencana terhadap Desa/Kelurahan yang belum ideal. Karena 1 orang petugas melayani 6 desa/kelurahan. Padahal idealnya untuk 1 orang petugas melayani 2 desa/kelurahan; (2) Pengetahuan dan keterampilan tentang program kependudukan keluarga berencana dan pembangunan keluarga (KKBPK) yang masih terbatas. Dalam pelaksanaannya PLKB belum sesuai dengan tugas yang diberikan, karena tidak semua PLKB mempunyai kemampuan yang memadai dan terampil dalam menjalankan tugasnya, sehingga berdampak terhadap hasil kinerja PLKB; (3) Masih kurangnya dana operasional Petugas Lapangan Keluarga Berencana (PLKB). Beberapa kendala diatas sangat mempengaruhi kinerja Petugas Lapangan Keluarga Berencana dalam meningkatkan pelayanan KB.

Kendala yang dihadapi masyarakat Desa dalam mendapatkan pelayanan KB adalah kurangnya pos-pos $\mathrm{KB}$ disetiap pedesaan dan jarak tempuh pos KB dari masyarakat yang jauh dari pedesaan sehingga masyarakat lebih banyak mengeluarkan biaya transportasi, waktu dan tenaga mereka untuk menuju pos KB. Biaya masyarakat desa lebih mahal dan sulit dibandingkan dengan masyarakat perkotaan untuk mendapatkan pelayanan KB dengan pendapatan masyarakat desa yang tidak begitu besar, karena itu masyarakat desa yang masih banyak tidak mengikuti program KB.

\section{METODE PENELITIAN}

Penelitian ini berusaha untuk mengetahui sejauh mana Peran Badan Kependudukan dan Keluarga Berencana
Nasional (BKKBN) Provinsi Bengkulu dalam pelatihan Petugas Lapangan Keluarga Berencana (PLKB). Untuk mencari jawaban tersebut maka peneliti menggunakan metode penelitian kualitatif deskriptif.

\section{Jenis Penelitian}

Adapun jenis penelitian yang digunakan berupa penelitian kualitatif maksudnya: penelitian yang dilakukan dengan menganalisis berupa langkah mengumpulkan data, mengklarifikasi data, mengelolah data, menganalisis data, dan akhirnya membuat kesimpulan. Hal ini di karenakan data yang akan disajikan dalam penelitian ini berbentuk kata-kata. (Masyhuri dan Zainuddin, 2008: 19).

Metode Penelitian yang digunakan adalah metode deskriptif, Penggunaannya dimaksudkan untuk memperoleh gambaran faktual tentang Peran Badan Kependudukan dan Keluarga Berencana Nasional (BKKBN) Provinsi Bengkulu dalam pelatihan Petugas Lapangan Keluarga Berencana (PLKB).

\section{Informan Penelitian}

Narasumber atau informan adalah orang-orang yang bisa memberikan informasi-informasi utama yang dibutuhkan dalam penelitian kita. Narasumber atau informan itulah yang dimaksud dengan subjek penelitian. Sedangkan untuk menentukan jumlah informan dalam penelitian ini tidak ada pembatasan yang mutlak. Oleh karena itu tehnik penentuan sample yang digunakan adalah tehnik sample yang bertujuan atau purpossive sampling Sugiyono, (2009:221).

Penentuan informan dengan metode purpossive sampling karena adanya maksud dan tujuan yang dianggap dapat mewakili populasi, waktu, biaya dan tenaga yang terbatas yang menjadikan tehnik sample ini diperlukan, namun tidaak tertutup kemungkinan informasi akan bertambah sesuai dengan kebutuhan informasi yang diinginkan serta ditentukan 
pada saat penelitian berlangsung yang sesuai dengan relevan atau tidaknya kebutuhan penelitian.

\section{Teknik Pengumpulan Data}

1. Observasi

2. Wawancara

3. Dokumentasi

\section{Teknik Analisa Data}

Dapat kita ketahui bahwa pengolahan dan analisi data dalam penelitian dilaksanakan melalui proses atau tahapan sebagai berikut:

\section{Pengumpulan Data}

Langkah awal dalam sebuah penelitian yaitu pengumpulan data. Pengumpulan data yang dimaksud dalam penelitian ini adalah proses pengumoulan data yang mempunyai kaitan dengan fokus penelitian. Semua data yang diperoleh melalui teknik dokumentasi dengan cara melakukan telaah pada dokumen yang berkaitan dengan masalah penelitian ini, serta menelaah literaturliteratur seperti buku, hasil penelitian lain dan profil BKKBN. Sedangkan semua data yang diperoleh dari hasil observasi dan wawancara yang dilaksanakan (seperti yang telah diuraikan pada teknik pengumpulan data). Selanjutnya melakukan pengumpulan data sekunder baik berupa catatan ataupun dokumentasi dari Kantor Perwakilan BKKBN Provinsi Bengkulu. Tahap selanjutnya dalam pengumpulan data, mengumpulkan data primer berupa hasil wawancara. Namun sesungguhnya proses ini bersifat fleksibel atau juga bisa dilakukan secara bersamaan.

2. Reduksi Data

Data yang diperoleh melalui proses pengumpulan data di lapangan jumlahnya cukup banyak. Data tersebut diperoleh dari wawancara peneliti dengan informan di lapanagan dalam bentuk catatan lapangan, dokumentasi, foto dan lain sebagainya. Oleh karena itu, perlu segera dilakukan pengolahan data dan analisis data melalui reduksi data. Mereduksi data berarti merangkum, memilih hal-hal yang pokok, memfokuskan pada hal-hal yang penting dan membuang hal-hal yang tidak penting. Pada tahap ini memusatkan perhatian pada data di Kantor Perwakilan BKKBN Provinsi Bengkulu. Data ini akan direduksi sehingga didapat kesimpulan tentang permasalahan yang ingin diteliti.

3. Penyajian Data

Setelah data direduksi, langkah selanjutnya yaitu menyajikan data. Penyajian data ini dilengkapi dengan analisi data yang bertujuan untuk menjelaskandan menguraikan berbagai data yang ada, serta dijelaskan satu persatu. Penelitian ini menggunakan bentuk penyajian data berupa teks yang bersifat naratif. Selian itu, dapat di lakukan dengan menampilkan gambar dan tabel hasil penelitian yang mendukung proses analisis.

4. Penarikan Kesimpulan

Kemudian langkah terakhir dalam proses ini yaitu penarikan kesimpulan. Kesimpulan yang dimaksud dalam penelitian ini ditemukan masalah yang sering terjadi. Permasalahan ini berupa deskripsi atau gambaran suatu objek yang menjadi permasalan sehingga setelah diteliti menjadi jelas.

\section{HASIL DAN PEMBAHASAN}

Hasil penelitian menunjukkan bahwa Peran Badan Kependudukan dan Keluarga Berencana Nasional (BKKBN) Provinsi Bengkulu dalam Pelatihan Petugas Lapangan Keluarga Berencana (PLKB didapatkan hasil jumlah PLKB terbanyak di Kabupaten Bengkulu Utara berjumlah 65 orang dan untuk jumlah PLKB paling sedikit di Kabupaten Kepahiang berjumlah 10 orang. Di lihat dari hasil perbandingan jumlah PLKB dengan jumlah Desa/Kel yang paling jauh dari kata ideal untuk jumlah PLKB ialah Kabupaten Seluma karena 1 petugas melayani 15 Desa/Kel di ikuti dengan Kabupaten Kepahiang 1 
orang petugas melayani 11 Desa/Kel. Untuk jumlah PLKB yang ideal terdapat di Kota Bengkulu karena 1 petugas melayani 2 Desa/Kel.

Berkenaan dengan Peran Badan Kependudukan dan Keluarga Berencana Nasional (BKKBN) Provinsi Bengkulu dalam Pelatihan Petugas Lapangan Keluarga Berencana (PLKB) dengan menggunakan landasan teori Peran Pemerintah menurut Faried Ali maka didapat pembahasan berikut ini:

\section{Stabilisator}

Stabilisator artinya peran pemerintah adalah dapat mengarahkan perubahan pada sasaran yang dikehendaki dengan suasana perubahan yang tertib dan terkendali. Pemerintah mewujudkan perubahan tetapi tidak menjadi suatu gejolak sosial, apalagi yang dapat menjadi ancaman bagi keutuhan nasional serta kesatuan daan persatuan bangsa. Peran tersebut dapat terwujud dengan menggunakan berbagai cara antara lain: kemampuan selektif yang tinggi, proses sosialisasi yang elegan tetapi efektif, melalui pendidikan, pendekatan yang persuasive dan pendekatan yang bertahap tetapi berkesinambungan.

a. Tujuan dari pelatihan PLKB ini adalah untuk meningkatkan pengetahuan dan keterampilan bagi PLKB dalam memantapkan dan menjaga keberlangsungan pelaksanaan program Kependudukan dan Keluarga Berencana di wilayah tugasnya. Untuk tujuan itu sudah tercapai dengan dilihat dari hasil pre test (soal sebelum mendapatkan materi) dan post test (soal setelah mendapatkan materi) peserta mengalami peningkatan dan pengetahuan peserta meningkat dengan adanya pelatihan. Mencapai tujuan dari pelatihan PLKB tergantung dari PLKB itu sendiri tercapai atau belum. Untuk peserta yang tercapai tujuan pelatihan itu seperti peserta mengikuti pelatihan yang serius dengan memperhatikan dan mencatat materi yang disampaikan agar meningkat pengetahuan peserta dan peserta yang belum tercapai tujuan pelatihan itu seperti mereka yang sibuk ngobrol dan main HP pada saat jam pelajaran berlangsung.

b. Hasil dari pelatihan PLKB ini PLKB dapat menerapkan pengetahuan yang mereka dapat selama pelatihan untuk diterapkan kelapangan. Peserta mendapatkan pembelakan pengetahuan untuk mengadakan pelayanan $\mathrm{KB}$ di lapangan dengan mencari akseptor $\mathrm{KB}$ dengan turun ke rumah-rumah masyarakat yang belum ikut KB maupun yang sudah ikut $\mathrm{KB}$, dan membantu PLKB dalam menjalankan tugas mereka di lapangan dalam meningkatkan program KKBPK di lapangan tempat tugas mereka.

c. Sasaran pelaksanaan dari pelatihan PLKB adalah PLKB dapat menyampaikan atau mensosialisasikan ilmu yang peserta dapat dari pelatihan untuk di praktekkan di pembinaan peserta masing-masing di tengah masyarakat seperti kelompok bina keluarga balita, remaja dan lansia dan PLKB juga dapat menjalankan program KKBPK di lapangan tempat tugas mereka. Dengan adanya pelatihan mereka termotivasi untuk menjalankan tugas menjadi aktif karena mereka sudah dibekali materi-materi atau ilmu pengetahuan dan ada juga materi seperti outbound untuk menambah semangat peserta menjalankan tugas di lini lapangan tempat tugas mereka.

2. Dinamisator

Dinamisator artinya peran pemerintah adalah dapat menggerakkan proses perubahan dalam waktu yang dikehendaki. Menggerakkan partisipasi masyarakat jika terjadi kendala-kendala dalam proses pembangunan untuk mendorong dan memelihara dinamika pembangunan. Pemerintah berperan melalui pemberian bimbingan dan pengarahan secara intensif dan efektif kepada masyarakat. Biasanya pemberian bimbingan diwujudkan melalui tim penyuluh maupun badan tertentu untuk memberikan pelatihan. 
a. Proses berlangsungnya pelatihan PLKB adalah pertama mengadakan rapat persiapan yang diikuti semua bidang, di dalam rapat persiapan itu membahas tentang materi-materi apa saya yang dibutuhkan dalam pelatihan, waktu pelatihan, menyiapkan administrasi seperti surat menyurat dan keuangan, menyiapkan sarana dan prasarana yang dibutuhkan dalam pelatihan dan hal-hal yang menyangkut tentang pelatihan. Dan menentukan waktu pelaksanaan pelatihan PLKB selama 5 hari setelah itu baru diselenggarakannya pelatihan PLKB.

b. Waktu pelaksanaan berlangsungnya pelatihan PLKB adalah dilaksanakan selama 5 hari, dalam 5 hari pelaksanaan pelatihan terdapat 40 jam pelajaran karena dalam 1 hari pelatihan terdapat 8 jam pelajaran dalam sehari.

c. Waktu pelaksanaan pelatihan PLKB selama 5 hari cukup untuk adanya perubahan bagi PLKB. Karena selama pelatihan itu ada semua yang dibutuhkan oleh PLKB seperti semua materi sudah disampaikan, dengan materi sudah disampaikan semua sudah pasti ada peningkatan pengetahuan bagi PLKB, ada outbound yang menambah semangat PLKB untuk bertugas kembali dan ada juga praktek lapangannya.

3. Inovator

Inovator artinya peran pemerintah adalah dapat menemukan hal-hal yang baru Apakah menyangkut metode ataupun strategi pencapaian dalam rangka perubahan yang dikehendaki. Jadi prakondisi yang harus terpenuhi agar efektif memainkan perannya pemerintah perlu memiliki tingkat keabsahan (legitimacy) yang tinggi. Suatu pemerintahan yang tingkat keabsahan yang rendah, misalnya karena "menang" dalam perebutan kekuasaan atau karena melalui pemilihan umum yang tidak jujur dan tidak adil, akan sulit menyodorkan inovasinya kepada masyarakat.
Tiga hal yang mutlak mendapatkan perhatian serius adalah, penerapan inovasi dilakukan dilingkungan birokrasi terlebih dahulu, inovasi yang sifatnya konsepsional, inovasi sistem, prosedur, dan metode kerja.

a. Menemukan hal-hal baru dari pelatihan PLKB adalah setelah pelatihan itu ada evaluasi, pengamatan dan masukan dalam pelatihan, peserta dapat mengeluarkan pendapat apa yang dibutuhkan yang kurang dari lapangan. Bisa diusulkan menjadi pelatihan untuk pelatihan yang akan datang dan PLKB juga bisa menyampaikan saran kepada BKKBN dan jika saran peserta itu baik dapat di respon untuk pelatihan ke depan yang lebih baik.

b. Strategi yang yang dilakukan dalam mencapai tujuan dari pelatihan PLKB adalah pelatihan PLKB ini dilaksanakan berdasarkan ketetapan dari pusat (kurikulum), pemberian materi yang sesuai dengan program KKBPK didalam materi PLKB merasa puas karena ada semua materi yang PLKB butuhkan dan pemateri yang profesional sesuai dengan materi itu. Dengan adanya pelatihan ini menambah pengetahuan, keterampilan dan pemahaman peserta. Namun untuk monitoring ke lapangan belum ada, BKKBN turun kelapangan pada saat ada kegiatan saja dan pada PLKB yang aktif saja.

c. Metode materi pelatihan PLKB adalah dengan masing-masing bidang menyampaikan materi tergantung materi yang dibutuhkan seperti bidang KB-KS dan seluruh bidang terkait didalam materi pelatihan itu. Pemateri menyampaikan materi di bantu dengan alas infokus, membuat waktu tanya jawab, dalam ruangan ada olahraga ringan agar peserta tidak jenuh dan ngantuk dalam belajar dan dalam jam pelajaran ada diskusi, pembagian kelompok kerja, praktek dari lapangan seperti praktek pelayanan KB, pembinaan kelompok dan ketahanan 
keluarga, ada juga refresingnya (outbound) dan rencana tindak lanjut setelah mendapatkan pelatihan untuk kita tahu apa yang mereka dapatkan dari hasil pelatihan.

\section{PENUTUP}

\section{Kesimpulan}

Berdasarkan hasil penelitian maka dapat disimpulkan bahwa Peran Badan Kependudukan dan Keluarga Berencana Nasional (BKKBN) Provinsi Bengkulu dalam pelatihan Petugas Lapangan Keluarga Berencana (PLKB) didasarkan teori peran pemerintah dalam pembangunan menurut Faried Ali (Faried, 2011:120) dapat dikatakan berjalan efektif hal ini dibuktikan dengan hasil penelitian.

1. Stabilisator

PLKB mendapatkan peningkatan pengetahuan dan keterampilan dalam pelatihan PLKB yang mereka ikuti, dilihat dari hasil pre test (soal sebelum mendapatkan materi) dan post test (soal setelah mendapatkan meteri). Namun tidak semua PLKB mengalami peningkatan karena merubah sikap seseorang tidak mudah dan pada saat jam pelajaran berlangsung tidak semua peserta memperhatikan dan mencatat materi, seperti PLKB yang ngobrol dan main HP pada saat jam pelajaran berlangsung. Dengan adanya pelatihan PLKB peserta dapat menerapkan ilmu yang mereka dapat dari pelatihan PLKB untuk disampaikan kepada masyarakat dan PLKB dapat lebih mudah mengadakan pelayanan $\mathrm{KB}$ di lini lapangan tempat tugas peserta masingmasing.

2. Dinamisator

Proses berlangsungnya pelatihan PLKB adalah pertama mengadakan rapat persiapan yang diikuti semua bidang, di dalam rapat persiapan itu membahas tentang materi-materi apa saya yang dibutuhkan dalam pelatihan, waktu pelatihan, menyiapkan administrasi seperti surat menyurat dan keuangan, menyiapkan sarana dan prasarana yang dibutuhkan dalam pelatihan. Dan waktu pelaksanaan pelatihan selama 5 hari dan terdapat 8 jam pelajaran dalam sehari. Waktu yang sediakan BKKBN cukup dengan diadakannya pelatihan selama 5 hari untuk perubahan bagi PLKB karena selama pelatihan itu sudah ada semua yang dibutuhkan oleh PLKB seperti materi cukup, ada Outbound untuk menambah semangat PLKB kembali ketempat tugas dan praktek lapangannya.

3. Inovator

BKKBN menemukan hal-hal baru dari pelatihan PLKB adalah setelah pelatihan ada evaluasi, pengamatan dan masukan dalam pelatihan, peserta dapat mengeluarkan pendapat apa yang dibutuhkan dan kurang dari lapangan. Bisa diusulkan menjadi pelatihan untuk pelatihan yang akan datang dan PLKB juga bisa menyampaikan saran kepada BKKBN dan jika saran peserta itu baik dapat di respon untuk pelatihan ke depan yang lebih baik. BKKBN memberikan materi sesuai dengan PLKB butuhkan dan pemateri juga sudah profesional untuk menyampaikan materi pelatihan dan dalam jam pelajaran ada diskusi, pembagian kelompok kerja, praktek dari lapangan, refresingnya (outbonud) dan rencana tindak lanjut.

\section{Saran}

Setelah melakukan penelitian, adapun saran yang dapat diberikan yaitu:

1. Pelaksanaan pelatihan PLKB untuk sebaiknya dilakukan 2 atau 3 kali dalam setahun, sehingga PLKB dapat memenuhi kebutuhan di lapangan.

2. Sebaiknya BKKBN melakukan monitoring kelapangan 3 bulan setelah pelatihan, sehingga dapat melihat perubahan kinerja PLKB.

3. Sebaiknya PLKB lebih serius lagi dalam mengikuti pelatihan PLKB yang dilaksankan oleh BKKBN. 
DAFTAR PUSTAKA

Ali, Faried. 2011. Teori dan Konsep Administrasi. PT Raja Grafindo Persada, Jakarta.

Hadiyanto, Drs. 2002. Profil Institusi Masyarakat Pedesaan. Badan Koordinasi Keluarga Berencana Nasional, Jakarta.

Handayani, Sri. 2010. Buku Ajar Pelayanan Keluarga Berencana. Pustaka Rihana, Yogyakarta.

Harahap, E.St. 2007. Istilah Peran (peran menurut para ahli dan faktor peranan). Gramedia Pustaka Utama, Jakarta.
Masyhuri. 2008. Metode Penelitian Kualitatif. Bumi Aksara, Jakarta.

Nasution. 1992. Metode Penelitian Deskriptif. Sinar Grafika, Jakarta.

Riani, Laksmi A. 2013. Manajemen Sumberdaya Manusia Masa Kini, Graha Ilmu, Yogyakarta.

Septina, Sri. 2012. Pengertian Peran dan Peranan (Edisi Revisi), Erlangga, Jakarta. 